\title{
The Development of Readiness Indicators for Transit-Oriented Areas
}

\author{
Dadang Iskandar ${ }^{1,2}$, R. Jachrizal Sumabrata ${ }^{1, *}$, Radhitya Abiyoga ${ }^{1}$ \\ ${ }^{1}$ Department of Civil Engineering, Faculty of Engineering, Universitas Indonesia, Depok, 16424, Indonesia \\ ${ }^{2}$ Department of Civil Engineering, Faculty of Engineering, Universitas Muhammadiyah Metro, Metro, 34111, Indonesia
}

Received December 28, 2020; Revised February 4, 2021; Accepted March 23, 2021

\begin{abstract}
Cite This Paper in the following Citation Styles
(a): [1] Dadang Iskandar, R. Jachrizal Sumabrata, Radhitya Abiyoga, "The Development of Readiness Indicators for Transit-Oriented Areas," Civil Engineering and Architecture, Vol. 9, No. 2, pp. 453-461, 2021. DOI: 10.13189/cea.2021.090218.
\end{abstract}

(b): Dadang Iskandar, R. Jachrizal Sumabrata, Radhitya Abiyoga (2021). The Development of Readiness Indicators for Transit-Oriented Areas. Civil Engineering and Architecture, 9(2), 453-461. DOI: 10.13189/cea.2021.090218.

Copyright $\odot 2021$ by authors, all rights reserved. Authors agree that this article remains permanently open access under the terms of the Creative Commons Attribution License 4.0 International License

\begin{abstract}
The diversion of people towards public transportation has become the main focus of the Central Government and this involves rearranging the areas traversed by mass transportation corridors through the concept of transit-based integration known as the Transit-Oriented Development (TOD) in order to overcome congestion problems in Greater Jakarta, especially the Jakarta area. However, these plans have raised concerns on the ability of the transit-oriented area to fully accommodate the TOD concepts and principles or just to serve as only a part of the property business owned by several parties. The implementation of the concept is also not optimal due to the lack of an appropriate tool to identify the readiness of an area to be developed into a transit-oriented area by the government and the actions required to unlock the potentials of the development. This research, therefore, used 22 indicators to determine whether an area fulfills the transit-oriented elements and the factors required for its preparation. This involved using literature studies to produce research variables after which a survey was conducted and tested for validity and reliability by the drafter, academics, experts, and practitioners. The indicators were developed into an assessment instrument consisting of 5 parts to represent the research variables and other 23 questions.
\end{abstract}

Keywords Variables, Indicators, Tools, Assessment, TOD

\section{Introduction}

Greater Jakarta is a metropolitan area formed due to the density in the Jakarta area as the capital city which is usually congested during the day and empty at night. There are usually 47.5 million trips per day in Greater Jakarta and approximately 3.5 million which make up $12.7 \%$ of the 28.1 million residents are commuters on round trips. This includes the movement of 704,186 people to South Jakarta, 652,199 people to Central Jakarta, 408,144 people to East Jakarta, 361,439 people to West Jakarta, and 303,783 people to North Jakarta. This leads to the problem of congestion in Jakarta and the city was ranked 7 th, with $53 \%$ and an average additional time of 26 minutes and extra 19 minutes in the morning, out of the cities having the highest congestion rate in the world. The trips from the surrounding area to Jakarta are expected to reach 240-300 minutes or 4-5 hours in 2029 if the network and integrated mass transportation are not reformed [1] and this congestion has the ability to cause both material and immaterial losses.

This means people need to be diverted to the use of public transportation and one of the problems observed with this is the rearrangement of the areas traversed by the mass transportation corridors such as the Mass Rapid Transit (MRT)/Light Rail Transit (LRT) depots, MRT stations-commuter-LRT trains, and the inter-city and TransJakarta bus stop. This arrangement problem can, however, be optimized through the use of a transit-based integrated area also known as the Transit-Oriented Development (TOD) which is an urban area designed to 
integrate transit functions with humans, activities, buildings, and public spaces in order to improve the access to public transportation and support passenger-carrying capacity. The Greater Jakarta Transportation Management Agency (Badan Pengelola Transportasi Jabodetabek/BPTJ) is targeting 47 TOD to maximize the use of integrated mass public transportation such as Bus Rapid Transit (BRT), MRT, and LRT. The city has 47 potential TOD areas and these include 22 TOD City and 25 TOD Sub City and Environment. Moreover, Jakarta's Spatial Layout Plan-Zoning Regulations for 2030 marks nine locations including the Harmoni, Dukuh Atas, Setiabudi, Manggarai, Blok M, Senen, Grogol, Pulo Gebang, and Jatinegara for TOD. The Jakarta government also mandated the PT. MRT Jakarta to become the operator of the TOD area in eight stations including Lebak Bulus, Blok M, Senayan, Istora, Bendungan Hilir, Setiabudi, Dukuh Atas, and Bundaran Hotel Indonesia [2].

The rampant TOD development plans in the Jabodetabek area, especially Jakarta, have raised concerns on the ability of transit-oriented area development to fully accommodate the TOD concepts and principles or whether it is only a section of the property business from several parties. [3] conducted a study to estimate the income from residential areas, offices and business centers in TOD-based regions, the TOD concept only as a way to transform the apartment and business buildings near the transfer point to a station [4]. Meanwhile, the less significant role of the government in the planning process is associated with the intersection of TOD with business interests and this is considered a misunderstanding factor in its interpretation due to several benefits it has the ability of providing to the general public when properly implemented.

The process, however, requires a specific combination of geographic, demographic, economic, and institutional factors to function effectively and complement each other. Meanwhile, the government does not have an assessment indicator to identify the readiness of an area for transit-oriented development and the actions needed to unlock the appropriate potentials. Therefore, this research was conducted to assess the extent to which an existing and potential transit station area is stated to be ready to be developed into a transit-oriented area through the use of some assessment factors which reflect the needs and tendencies of TOD.

The development of the readiness indicators for the transit-oriented area in this research was based on the following objectives:

1. What are the indicators with the ability to define transit-oriented area development and are required in its preparation?

2. What are the factors to compile the indicators needed to reflect the standardization of transit-oriented development needs and trends?
3. What assessment tools can be used to identify, evaluate, and assess the readiness of an area for transit-oriented development, and what actions are needed to unlock the potential of this development?

\section{Transit-Oriented Development}

The term "Transit-Oriented Development" appeared for the first time in the 1990s and was pioneered by Peter Calthorpe due to the urban sprawl phenomenon which led to the high use of private vehicles and was followed by congestion $[4,5]$.

The concept was reported by Tamin [6] to be based on the deteriorating quality of urban life as marked by congestion, sprawl, and non-integrated land use and was initiated to create a comfortable, safe, pleasant, and adequate walkable environment for pedestrian. It involves mixing several functions which are central to commercial areas, offices, retail, service, medium to high-density residential areas, and public open spaces to ensure travel activities are shorter and faster.

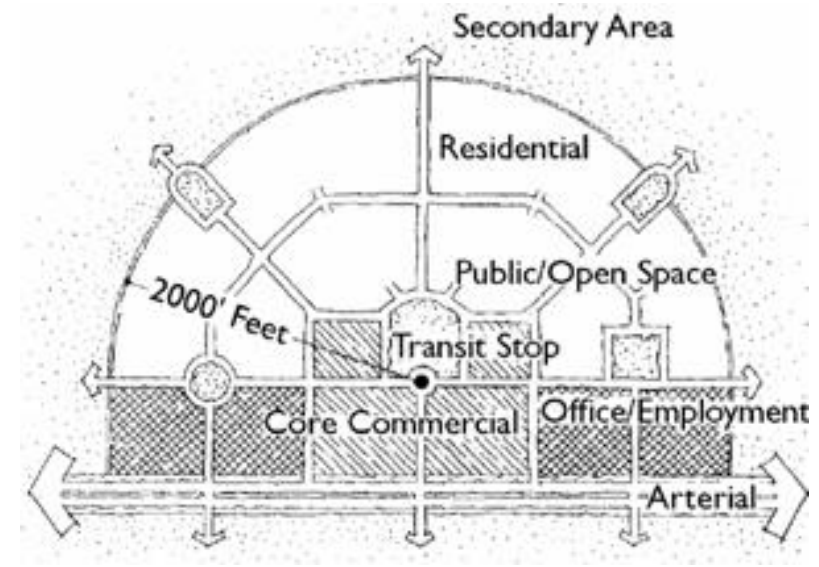

Figure 1. TOD Concept

The TOD concept offers an alternative development pattern by providing working, living, and leisure functions in a diverse population ranging from low to high density with pedestrian facilities and transit access configurations. The studied city is characterized by high diversity and density on a local and regional scale and connected to other city parts through a transit system. Therefore, the TOD started with the human movement activity concept both through the use of the mode of transportation and by walking. This is necessary because the movement is one of the activities mostly conducted by humans and it is required to have activity centers integrated with the transit points to promote the use of public transportation. These centers are connected to one another within comfortable and safe walking distances in an effort to reduce intermodal shifting [7].

There are, however, two development models in TOD according to Calthorpe [8] and they include the following: 


\section{- Neighborhood TOD}

This is located on the feeder bus line with a walk distance of 10 minutes or nor more than 3 miles from the transit point. It is required in a medium-density residential environment, public facilities, services, retail, and recreation and usually designed to have public facilities and green open spaces with easy access for the mode users, shown in Figure 2 (bottom).

\section{- Urban TOD}

This covers a whole city and usually includes the main circulation lines such as the intercity bus stops and train stations for both light and heavy rails. This type is expected to be developed in conjunction with high-intensity commercial functions, office blocks, and medium-high-intensity residences. Each TOD in a city, however, has its character according to the environment, shown in Figure (top).

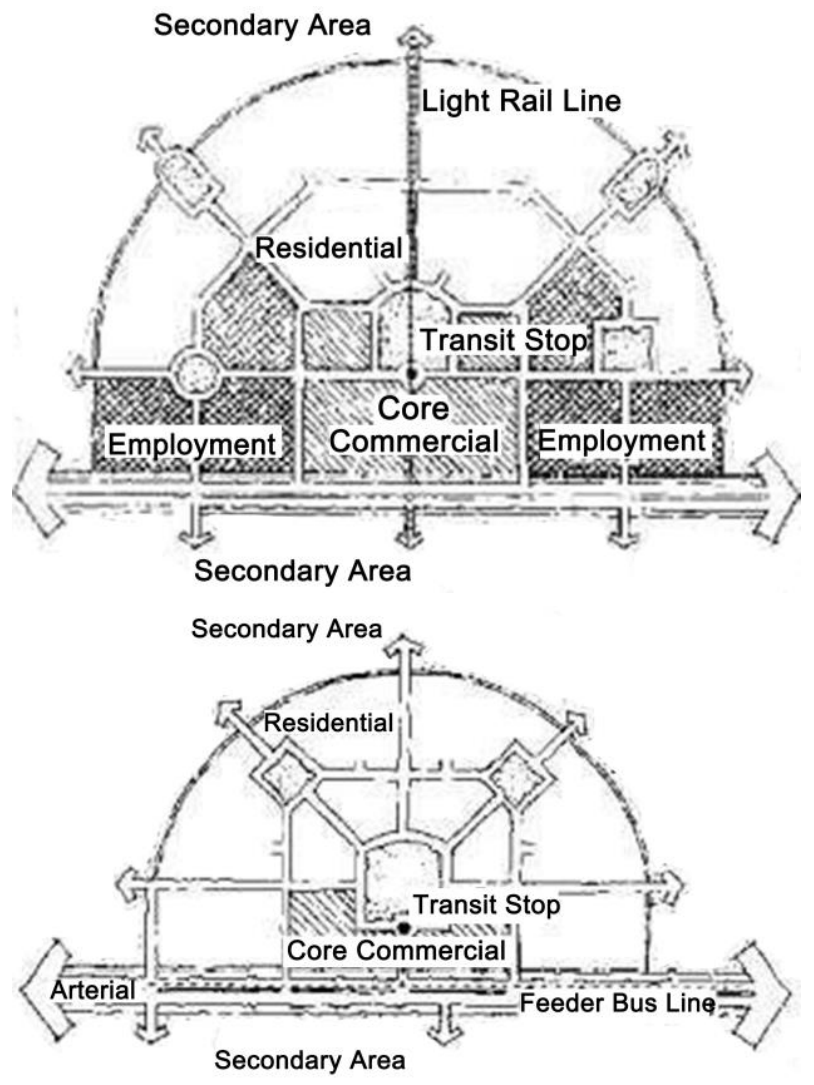

Figure 2. Urban TOD's (top) and Neighborhood TOD's (bottom) [8]

\subsection{Regulation from the Minister of Agrarian Affairs and Spatial Planning/Head of the Indonesian National Land Agency Number 16 of 2017 on Guidelines for Transit-Oriented Area Development}

The government, through the Ministry of Agrarian Affairs and Spatial Planning/National Land Agency (ATR/BPN), has officially issued a property regulation Balaid related to the guidelines for transit-oriented area development as regulated in Ministerial Regulation no 16 of 2017. This is based on the high level of property development in line with transit-based or Transit-Oriented Development. The ministerial focuses on the principles of TOD, location determination, and development of the normal and institutional TOD areas [9].

The minimum requirements for an area to be developed using this concept according to the Ministerial Regulation include having in-transit rail-based high capacity mass public transport networks, fulfilling the requirements for intermodal and intermodal transit, served by at least 1 short-distance transit mode and 1 (one) long-distance transit mode in accordance with the development of service centers and activities, and located in an area with low disaster vulnerability as well as ensuring non-disturbance of important state installations. Meanwhile, the focus of this research was restricted to the area with mass transportation system services, service centers development, and some other activities stated as follows:

- City TOD area which is located at a service center within a city area and having a service function on a regional scale or an urban area and within a regency area is designated as the activity center.

- Sub-city TOD area which is located at a service sub-center within a city area and having service functions on a city scale, in the part of the city or an urban area and within a regency area is designated as the activity center.

- Environmental TOD area which is located at the center of environmental services within the city area and functioning in an environmental scale or urban area within the regency area is designated as the activity center.

\subsection{Jakarta Provincial Governor Regulation Number 44 of 2017 concerning Guidelines for the TOD Area Development}

Jakarta Provincial Government issued a property regulation Beleid related to the TOD area development guidelines as stipulated in the Jakarta Provincial Governor Regulation Number 44 of 2017. This regulation is based on the high level of property development based on transit-based or Transit-Oriented Development which was initiated from Jakarta. This regulation also focuses on the Principles of Planning, Classification and Criteria for TOD Area Development, TOD Area Development Mechanism, Technical Directions for Utilizing TOD Areas, and the Development and Management Process [10].

The general criteria to determine the TOD area include having two or more mass transport corridor intersections with one being rail-based, located in areas with high economic value and/or predicted to have high economic value, and being in the areas planned and/or designated as 
the activity center. Meanwhile, the technical criteria include having an area with a radius of $350 \mathrm{~m}$, consisting of offices, trade, and services, Mixed Zones, Housing, Government, as well as public and social service zones [11]. The carrying capacity of mass public transportation and/or terminals was subsequently added with the number of passengers and presence of a feeder system such as intermodal integration systems, time for intermodal transfers, availability of park and ride facilities, the time between vehicles, and integration between transportation modes, and capacity used as the indicators. The carrying capacity of the environment is, however, expected to be in accordance with the results of the environmental impact assessment and traffic impact [12].

\subsection{TOD Standard by ITDP}

The TOD Standard is a policy summary, assessment tool, and a recognition system designed by the Institute for Transportation and Development Policy (ITDP). As a policy summary, it describes the basic principles of inclusive TOD and identifies important key targets to implement the principles in urban development. As an assessment tool, it supports urban development products based on its relationship with the TOD principles and goals by distributing 100 points on 25 quantitative metrics designed to measure the implementation of the 8 principles and 14 specific targets [13]. Lastly, it functions as a recognition system to provide awards with bronze, silver, and gold levels for development projects based on the successful assessment of the performance towards achieving TOD targets and realizing its principles[14].

\subsection{Transit-Oriented Development (TOD) Readiness Tool by Florida Department of Transportation and Community Affairs}

The TOD Readiness Tool is an instrument designed to assist planners and stakeholders in analyzing the value of an existing or potential future area. It has three components and the first is the User Guide to provide instructions on how to use the tool, the purpose of each action, and technical notes, the second is an interactive Excel spreadsheet tool which is usually used for readiness assessment, and the third is a two-page summary template which is integrated into Excel spreadsheet tools for clear presentation of the assessment results. This tool is intended to be completed by the Government or the planners and the two-page summary chart is useful in presenting the assessment results to several interested stakeholders, shown in Figure 3 [14-16].

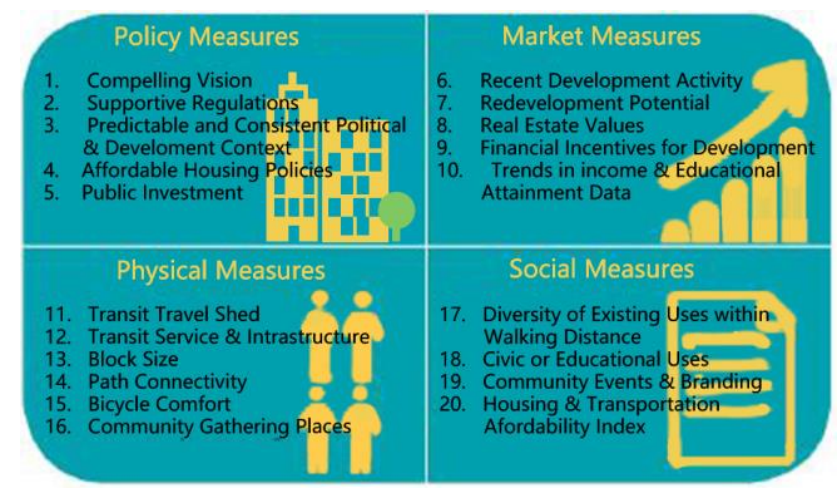

Figure 3. Principles and Assessment of TOD Readiness Tool

\section{Methods}

This research was conducted using quantitative analysis methods and this involved testing the validity and reliability of the questionnaires distributed to experts, academics, drafters, and practitioners to evaluate the research indicators. Moreover, the indicators were developed based on the compilation of variables retrieved from literature studies related to principles and indicators in transit-oriented development. It is important to note that 6 variables were derived from 9 studies while secondary data were also obtained through the GIS application such as the Google Earth application during the process of testing the research instrument [17].

\subsection{Temporary Research Indicators}

The variables were reduced from the principles of the concept to the target of this research in line with the objectives formulated and a total of 31 untested provisional indicators were obtained from the 6 variables which were retrieved from previous scientific journals and several other additional references as shown in the following table 1 . 
Table 1. Temporary Research Indicators

\begin{tabular}{|c|c|c|}
\hline No & Variables & Indicators \\
\hline \multirow{3}{*}{1.} & \multirow{3}{*}{ Mix Used Land } & Educational facilities (M1, M2, M3, M4, M5) \\
\hline & & Health facilities (M6) \\
\hline & & Fresh shopping facilities (M7) \\
\hline \multirow{5}{*}{2.} & \multirow{5}{*}{ Access and Accessibility } & Distance to major modes of transportation $(\mathrm{A} 1, \mathrm{~A} 3)$ \\
\hline & & Distance with other alternative modes of transportation (A2) \\
\hline & & Distance from health facilities (A5) \\
\hline & & Distance to fresh shopping (A6) \\
\hline & & Distance to educational facilities (A4) \\
\hline \multirow{3}{*}{3.} & \multirow{3}{*}{ Density } & Population density at nearby locations (D2) \\
\hline & & Building Floor Coefficient/KLB (D1) \\
\hline & & Basic Building Coefficient/KDB (D1) \\
\hline \multirow{4}{*}{4.} & \multirow{4}{*}{ Socio Economic Development } & Distance to parks or open spaces around the site (SE1) \\
\hline & & Availability of space allocation plans in parks or open spaces at locations (SE2) \\
\hline & & Availability of space allocation plans for retail functions at locations (SE3) \\
\hline & & Number of businesses standing per square kilometer around the site (SE4) \\
\hline \multirow{6}{*}{5.} & \multirow{6}{*}{ Access on foot and ride a bike } & Assessment of the existing pedestrian length (WC1) \\
\hline & & The existence of equality facilities for pedestrians (WC2) \\
\hline & & The existence of security facilities on the pedestrian (WC3) \\
\hline & & The existence of comfort facilities on the pedestrian (WC4) \\
\hline & & The existence of a bicycle parking facility (WC5) \\
\hline & & The existence of a special bicycle path (WC6) \\
\hline \multirow{5}{*}{6.} & \multirow{5}{*}{ Transit Stops } & The existence of equal facilities at the transit point (TS1) \\
\hline & & The presence of visual information at the transit point (TS2) \\
\hline & & The presence of audio information at the transit point (TS3) \\
\hline & & $\begin{array}{l}\text { Availability of officers on duty (TS4) } \\
\text { Suitability of arrival and departure times of public transportation modes (TS5) }\end{array}$ \\
\hline & & The suitability of the frequency of travel for public transportation modes (TS6) \\
\hline
\end{tabular}

These research indicators were processed in the form of a questionnaire to obtain responses from the drafters, experts, academics, and practitioners after which their responses were tested for validity and reliability to produce fixed research indicators.

\subsection{Validity Test}

The questionnaire was designed in the form of a Likert scale with an interval of 1-5 and the data obtained were parametric. Therefore, the validity test was conducted using the Pearson Product Moment correlation coefficient which is most commonly used to measure the correlation of parametric data. The responses of the respondent obtained from the survey were used and the validity was calculated using the following formula [18](1).

$$
\mathrm{r}_{\mathrm{xy}}=\frac{n \sum X Y-\left(\sum X\right)\left(\sum Y\right)}{\sqrt{\left(n \sum X^{2}-\left(\sum X\right)^{2}\right)\left(n \sum Y^{2}-\left(\sum Y\right)^{2}\right)}}
$$

The invalid indicators are, however, stated as follows table 2: 
Table 2. Validity Test Results

\begin{tabular}{|c|c|c|c|c|c|}
\hline & & SUM & & & SUM \\
\hline \multirow[t]{3}{*}{ M1 } & $\begin{array}{c}\text { Pearson } \\
\text { Correlation }\end{array}$ & $.678^{++}$ & D2 & $\begin{array}{c}\text { Pearson } \\
\text { Correlation }\end{array}$ & $.513^{++}$ \\
\hline & Sig. (2- tailed) & .001 & & Sig. (2-tailed) & .017 \\
\hline & $\mathrm{N}$ & 21 & & $\mathrm{~N}$ & 21 \\
\hline \multirow[t]{3}{*}{ M2 } & $\begin{array}{c}\text { Pearson } \\
\text { Correlation }\end{array}$ & $.862^{++}$ & SE1 & $\begin{array}{c}\text { Pearson } \\
\text { Correlation }\end{array}$ & $.634^{++}$ \\
\hline & Sig. (2- tailed) & .000 & & Sig. (2- tailed) & .002 \\
\hline & $\mathrm{N}$ & 21 & & $\mathrm{~N}$ & 21 \\
\hline \multirow[t]{3}{*}{ M3 } & $\begin{array}{c}\text { Pearson } \\
\text { Correlation }\end{array}$ & $.904^{++}$ & SE3 & $\begin{array}{c}\text { Pearson } \\
\text { Correlation }\end{array}$ & $.467^{++}$ \\
\hline & Sig. (2- tailed) & .000 & & Sig. (2- tailed) & .033 \\
\hline & $\mathrm{N}$ & 21 & & $\mathrm{~N}$ & 21 \\
\hline \multirow[t]{3}{*}{ M4 } & $\begin{array}{c}\text { Pearson } \\
\text { Correlation }\end{array}$ & $.870^{++}$ & TS4 & $\begin{array}{c}\text { Pearson } \\
\text { Correlation }\end{array}$ & $.529^{++}$ \\
\hline & Sig. (2- tailed) & .000 & & Sig. (2- tailed) & .014 \\
\hline & $\mathrm{N}$ & 21 & & $\mathrm{~N}$ & 21 \\
\hline \multirow[t]{3}{*}{ M5 } & $\begin{array}{c}\text { Pearson } \\
\text { Correlation }\end{array}$ & $.822^{++}$ & & & \\
\hline & Sig. (2- tailed) & .000 & & & \\
\hline & $\mathrm{N}$ & 21 & & & \\
\hline \multirow[t]{3}{*}{ M6 } & $\begin{array}{c}\text { Pearson } \\
\text { Correlation }\end{array}$ & $.839^{++}$ & & & \\
\hline & Sig. (2- tailed) & .000 & & & \\
\hline & $\mathrm{N}$ & 21 & & & \\
\hline \multirow[t]{3}{*}{ M7 } & $\begin{array}{c}\text { Pearson } \\
\text { Correlation }\end{array}$ & $.890^{++}$ & & & \\
\hline & Sig. (2- tailed) & .000 & & & \\
\hline & $\mathrm{N}$ & 21 & & & \\
\hline
\end{tabular}

\subsection{Reliability Test}

The reliability test was conducted using Alpha Cronbach using the answers from respondents and calculated using the following equation (2):

$$
\mathrm{r}_{11}=\left(\frac{k}{k-1}\right)\left(1-\frac{\sum \sigma_{b}^{2}}{\sigma_{t}^{2}}\right)
$$

Where:

$\mathrm{r}_{11}=$ instrument reliability (Cronbach's alpha coefficient)

$\mathrm{k}=$ number of questions

$\sigma_{\mathrm{b}}^{2}=$ number of variances

$\sigma_{\mathrm{t}}^{2}=$ total variances
The unreliable indicators are, however, stated as follows table 3 :

Table 3. Reliability Test Results

\begin{tabular}{|c|c|c|c|c|}
\hline & $\begin{array}{l}\text { Scale Mean } \\
\text { if Item } \\
\text { Deleted }\end{array}$ & $\begin{array}{c}\text { Scale } \\
\text { Variance if } \\
\text { Item Deleted }\end{array}$ & $\begin{array}{l}\text { Corrected } \\
\text { Item-Total } \\
\text { Correlation }\end{array}$ & $\begin{array}{c}\text { Cronbach's } \\
\text { Alpha if } \\
\text { Item } \\
\text { Deleted }\end{array}$ \\
\hline M1 & 119.3810 & 108.248 & .469 & .807 \\
\hline M2 & 119.2381 & 104.190 & .685 & .797 \\
\hline M3 & 119.0952 & 100.690 & .766 & .791 \\
\hline M4 & 119.0952 & 100.390 & .723 & .792 \\
\hline M5 & 119.0000 & 99.100 & .756 & .790 \\
\hline M6 & 119.0952 & 107.490 & .604 & .802 \\
\hline M7 & 118.7143 & 102.914 & .723 & .794 \\
\hline $\mathrm{A} 1$ & 117.3810 & 119.248 & .073 & .820 \\
\hline $\mathrm{A} 2$ & 117.1429 & 120.629 & .000 & .819 \\
\hline $\mathrm{A} 3$ & 118.4762 & 118.362 & .043 & .826 \\
\hline A4 & 118.9048 & 114.290 & .270 & .815 \\
\hline A5 & 118.9524 & 112.948 & .447 & .809 \\
\hline A6 & 119.1429 & 124.329 & -.217 & .833 \\
\hline D1 & 117.9524 & 115.648 & .225 & .816 \\
\hline D2 & 118.3810 & 107.848 & .487 & .806 \\
\hline SE1 & 118.3810 & 106.648 & .598 & .801 \\
\hline SE2 & 117.8571 & 117.629 & .185 & .817 \\
\hline SE3 & 117.8095 & 114.862 & .439 & .811 \\
\hline SE4 & 118.2857 & 113.814 & .308 & .813 \\
\hline WC1 & 117.9048 & 112.190 & .406 & .810 \\
\hline WC2 & 117.5238 & 114.062 & .381 & .811 \\
\hline WC3 & 117.5238 & 115.962 & .412 & .812 \\
\hline WC4 & 117.8095 & 111.662 & .455 & .808 \\
\hline WC5 & 117.4286 & 117.057 & .335 & .814 \\
\hline WC6 & 117.5714 & 119.957 & .024 & .821 \\
\hline WC7 & 117.6190 & 120.348 & -.006 & .821 \\
\hline TS1 & 117.5238 & 119.062 & .121 & .818 \\
\hline TS2 & 117.8571 & 129.329 & -.464 & .840 \\
\hline TS3 & 117.8571 & 127.829 & -.393 & .838 \\
\hline TS4 & 117.7619 & 112.590 & .343 & .812 \\
\hline TS5 & 117.6190 & 114.048 & .288 & .814 \\
\hline
\end{tabular}


Table 4. Tested Indicators

\begin{tabular}{|c|c|c|c|}
\hline No. & Code & Variable & Indicator \\
\hline 1. & A1 & \multirow{6}{*}{ Accessibility } & There are at least 2 modes of public transportation serving the area \\
\hline 2. & A2 & & $\begin{array}{l}\text { There is an integration route between one mode and other public } \\
\text { transportations }\end{array}$ \\
\hline 3. & A3 & & $\begin{array}{l}\text { The ideal walking distance to any mode of transportation is less than } 250 \\
\text { meters }\end{array}$ \\
\hline 4. & A4 & & The farthest distance from educational facilities is 1000 meters \\
\hline 5. & A5 & & The farthest distance from health facilities is 1000 meters \\
\hline 6. & A6 & & The farthest distance from shopping facilities is 1000 meters \\
\hline 7. & D1 & Density & $\begin{array}{l}\text { KDB (Basic Building Coefficient) and KLB (Building Floor } \\
\text { Coefficient) Value of building projects }\end{array}$ \\
\hline 8. & SE2 & \multirow{3}{*}{ Socio-Economic Development } & The existence of a park at the project site \\
\hline 9. & SE3 & & The existence of a space for retail designation at the project site \\
\hline 10. & SE4 & & Number of businesses per square kilometer \\
\hline 11. & WC1 & \multirow{6}{*}{$\begin{array}{l}\text { Pedestrian and Cycling } \\
\text { Infrastructure }\end{array}$} & Assessment of the existing pedestrian length \\
\hline 12. & WC2 & & The existence of equality facilities for pedestrians \\
\hline 13. & WC3 & & The existence of security facilities on the pedestrian walkway \\
\hline 14. & WC4 & & The existence of leisure facilities on the pedestrian walkway \\
\hline 15. & WC5 & & The existence of bicycle parking facilities \\
\hline 16. & WC6 & & The existence of an independent bicycle path \\
\hline 17. & TS1 & \multirow{6}{*}{ Transit Facility } & Existence of Equality Facilities at Transit Points \\
\hline 18. & TS2 & & Existence of Visual Information at Transit Points \\
\hline 19. & TS3 & & Existence of Audio Information at Transit Points \\
\hline 20. & TS4 & & The presence of officers at the Transit Point \\
\hline 21. & TS5 & & $\begin{array}{l}\text { The suitability of the arrival and departure times for public } \\
\text { transportation modes }\end{array}$ \\
\hline 22. & TS6 & & The suitability of the travel frequency for public transportation modes \\
\hline
\end{tabular}

\subsection{Tested Research Indicators}

The validity and reliability tests previously conducted showed the M1, M2, M3, M4, M5, M6, M7, SE1, and D2 variables were not included in the indicators because their values are classified as low in both tests. Meanwhile, SE3, TS4, A5, and WC4 variables were included because they were only mentioned in one of the tests and this means they need to be considered in determining the transit-oriented development readiness of the study area as indicated in the table 4 .

The indicators in the table are expected to be used in designing an assessment instrument to be discussed in the Analysis of Research Results. It is important to note that the factors used for the compilation of indicators according to guidelines before the instrument was designed were formulated to be used as the standard for other assessment instruments based on AHP. Moreover, the type of assessment to be used is expected to be adjusted to this standardization, and the questions presented in the instrument were divided with the variable representing the tested indicators [19].

\section{Analysis of the Research Results}

\subsection{Rating of Assessment Instruments}

Analytical Hierarchy Process (AHP) was used and the questions used to represent the indicators on each variable were rated. In this case, the accessibility variable was specifically divided into 2 parts as observed in questions 1-4 and 5-7 to differentiate the priority level. Therefore, variables A1 and A2 were used for accessibility, D for density, SE for socio-economic development, WC for pedestrian and cycling infrastructure, and TS for transit facilities [20].

The first step was to determine the relative importance of each variable by making judgments in order to determine the ranking of the criteria. The values used include 1 for equal, 2 for moderate, 3 for strong, 4 for very strong, and 5 for extreme and these were used to produce a pairwise comparison table as shown in the following table 5 and 6. 
Table 5. Comparison of Relative Importance for Neighborhood Typologies

\begin{tabular}{|c|c|c|c|c|c|c|}
\hline \multicolumn{7}{|c|}{ Neighborhood TOD } \\
\hline & A1 & A2 & D & SE & WC & TS \\
\hline A1 & 1 & 3 & 5 & 4 & 1 & 2 \\
\hline A2 & 0.3333 & 1 & 3 & 2 & 0.3333 & 0.5 \\
\hline D & 0.2 & 0.3333 & 1 & 0.5 & 0.25 & 0.25 \\
\hline SE & 0.25 & 0.5 & 2 & 1 & 0.2 & 0.3333 \\
\hline WC & 1 & 3 & 4 & 5 & 1 & 2 \\
\hline TS & 0.5 & 2 & 4 & 3 & 0.5 & 1 \\
\hline
\end{tabular}

Table 6. Comparison of Relative Importance for Urban Typologies

\begin{tabular}{|c|c|c|c|c|c|c|}
\hline \multicolumn{7}{|c|}{ Urban TOD } \\
\hline & A1 & A2 & D & SE & WC & TS \\
\hline A1 & 1 & 4 & 5 & 1 & 2 & 3 \\
\hline A2 & 0.25 & 1 & 2 & 0.25 & 0.3333 & 0.3333 \\
\hline D & 0.2 & 0.5 & 1 & 0.2 & 0.25 & 0.25 \\
\hline SE & 1 & 4 & 5 & 1 & 2 & 3 \\
\hline WC & 0.5 & 3 & 4 & 0.5 & 1 & 2 \\
\hline TS & 0.3333 & 3 & 4 & 0.3333 & 0.5 & 1 \\
\hline
\end{tabular}

The squaring, calculation and normalization of the Eigen factor matrix produced the rating for each variable which were later represented in the form of a section in the assessment instrument as indicated in the following table 7 .

Table 7. Rating of Each Variable

\begin{tabular}{|c|c|c|c|}
\hline \multicolumn{2}{|c|}{ Neighborhood } & \multicolumn{2}{c|}{ Urban } \\
\hline 29 & A1 & 29 & A1 \\
\hline 11 & A2 & 6 & A2 \\
\hline 5 & D & 5 & D \\
\hline 7 & SE & 29 & SE \\
\hline 30 & WC & 18 & WC \\
\hline 18 & TS & 13 & TS \\
\hline 100 & & 100 & \\
\hline
\end{tabular}

\section{Conclusions}

- The purpose of this research was to compile the indicators and constituent factors required to develop an assessment instrument to assess the readiness of an area for transit-oriented development and also to determine the actions needed to unlock the potential of the development process.

- A review of past studies produced 6 constituent variables of TOD readiness with 31 indicators.

- The validity and reliability tests conducted on the respondent's responses produced 5 variables with 21 indicators.
The accessibility variable consists of indicators as observed in at least 2 modes of public transportation serving the area, an integration path between one mode and another, an ideal walk distance of less than $250 \mathrm{~m}$ to the mode of transportation, and the furthest distance of $1000 \mathrm{~m}$ from educational, health, and shopping facilities.

The density variable consists of indicators such as the KDB and the KLB value of the building project. Meanwhile, the socio-economic development variable includes indicators such as the presence of parks and space for retail designation at the project location and an appropriate number of businesses per square kilometer.

- The pedestrian and cycling infrastructure variables consist of indicators such as the length of the existing pedestrians, existence of equality, security facilities, and leisure facilities on the pedestrian walkway, existence of bicycle parking facilities, and the provision of an independent bicycle path.

- The transit facility variable consists of indicators such as the existence of equality, visual and audio information facilities at the transit points, presence of officers on duty at transit points, and the suitability of arrival and departure times as well as travel frequency for public transportation modes.

- This assessment instrument has 5 parts with 23 questions representing each of the research variables. The assessment was divided into 2 parts according to the 2 standardizations considering the fact that there is a type with 3 parts which involves using a Yes/No response and confirming the answer with descriptions.

- The rating emphasized the importance of the questions on the aspects of transportation connectivity modes, walking, and cycling activities, and transit facilities which are observed to be the reformers of the TOD, especially with the focus on its readiness.

\section{Acknowledgments}

This research was funded by the Direktorat Riset dan Pengabdian Masyarakat Universitas Indonesia through the PUTI Saintekes Grant 2020, funded by contract no. NKB-2446/UN2.RST/HKP05.00/2020, April 29, 2020. The authors thank to The Transportation Laboratory of the Universitas Indonesia Civil Engineering Department

\section{REFERENCES}

[1] BPTJ, "Performance Report of Government Agencies, Directorate of Infrastructure, Ministry of Transportation," p. 43, 2017. 
[2] P. MRT, "Annual Report MRT Jakarta 2019," 2019.

[3] M. A. Berawi and M. Sari, "Optimizing property income in transit oriented development: A case study of Jakarta TOD," Civil Engineering and Architecture, vol. 8, no. 2, pp. 136-143, 2020.

[4] S. Sulistyaningrum and J. Sumabrata, "Transit Oriented Development (TOD) index at the current transit nodes in Depok City, Indonesia," in IOP Conference Series: Earth and Environmental Science, 2018, vol. 126, no. 012217: IOP Publishing Ltd., pp. 1755-1315.

[5] H. Taki, M. Maatouk, R. Koestoer, and S. Moersidik, "Spatial planning for potential green TOD using suitability analysis at the metropolitan region scale," in IOP Conf. Ser. Earth Environ. Sci, 2018, vol. 160, p. 012020.

[6] Z. T. Ofyar, "Perencanaan dan Permodelan Transportasi," Bandung: ITB, 2000.

[7] N. L. A. Widyahari and P. N. Indradjati, "The potential of transit-oriented development (tod) and its opportunity in Bandung metropolitan area," Procedia Environmental Sciences, vol. 28, pp. 474-482, 2015.

[8] C. Associates, "Transit-Oriented Development Design Guidelines," ed: Sacramento County Planning and Community Development Department Sacramento, CA, 1990.

[9] M. A. BPN, "Peraturan Menteri ATR BPN No 16 Tahun 2017 tentang Pedoman Pengembangan Kawasan Berorientasi Transit," 2017.

[10] G. P. DKI, "Pergub Prov. DKI Jakarta tentang Pengembangan Kawasan Transit Oriented Development," p. $12,2017$.

[11] R. Daniels and C. Mulley, "Explaining walking distance to public transport: The dominance of public transport supply," Journal of Transport and Land Use, vol. 6, no. 2, pp. 5-20, 2013.
[12] J. B. Cicchino et al., "Not all protected bike lanes are the same: infrastructure and risk of cyclist collisions and falls leading to emergency department visits in three US cities," Accident Analysis \& Prevention, vol. 141, p. 105490, 2020.

[13] D. Kim, "The transportation safety of elderly pedestrians: Modeling contributing factors to elderly pedestrian collisions," Accident Analysis \& Prevention, vol. 131, pp. 268-274, 2019.

[14] D. J. Treffinger, "Creative problem solving: Overview and educational implications," Educational Psychology Review, vol. 7, no. 3, pp. 301-312, 1995.

[15] P. Fan, Y.-C. Lee, Z. Ouyang, and S.-L. Huang, "Compact and green urban development towards a framework to assess urban development for a high-density metropolis," Environmental Research Letters, vol. 14, no. 11, p. 115006 , 2019.

[16] Z. Asadi-Shekari, M. Moeinaddini, and M. Z. Shah, "Pedestrian safety index for evaluating street facilities in urban areas," Safety science, vol. 74, pp. 1-14, 2015.

[17] G. D'Orso and M. Migliore, "A GIS-based method for evaluating the walkability of a pedestrian environment and prioritised investments," Journal of transport geography, vol. 82, p. 102555,2020 .

[18] L. Eboli, Y. Fu, and G. Mazzulla, "Multilevel comprehensive evaluation of the railway service quality," Procedia Engineering, vol. 137, no. 4, pp. 21-30, 2016.

[19] A. El-Geneidy, M. Grimsrud, R. Wasfi, P. T - -treault, and J. Surprenant-Legault, "New evidence on walking distances to transit stops: Identifying redundancies and gaps using variable service areas," Transportation, vol. 41, no. 1, pp. 193-210, 2014.

[20] L. Eboli and G. Mazzulla, "Key factors affecting rail service quality in the Northern Italy: a decision tree approach," Transport, vol. 29, no. 1, pp. 75-83, 2014. 